\title{
Gingival Grafts for Orthodontic Treatment: Is it Possible to Perform them in a Conventional Way in Patients with Systemic Lupus Erythematosus? \\ Julien Rodrigues Pires ${ }^{1 *}$, Sofia Wanderley Cavalcanti de Albu- querque ${ }^{2}$, Leopoldo Luiz dos Santos Neto ${ }^{3}$, Larissa Pessoa ${ }^{4}$ and Adriana Campos Passanezi Sant 'Ana' ${ }^{1}$
}

${ }^{1}$ Discipline of Periodontics, Department of Prosthodontics and Periodontics, School of Dentistry at Bauru, University of São Paulo, Bauru, Brazil

${ }^{2}$ Orthodontist, Orthocare - Brasilia-DF

${ }^{3}$ Department of Rheumatology, University Hospital of Brasília, (HUB-UnB), Brazil

${ }^{4}$ Department of Dentistry, Paulista University, Brasília, Brazil

\begin{abstract}
Systemic lupus erythematosus (SLE) is an autoimmune disease of the connective tissue, whose immune system attacks the body's own cells, resulting in inflammation and tissue damage. SLE can affect any part of the body, since autoantibodies (anti-DNA) have an affinity for DNA. Few studies have evaluated periodontal disease and dental interventions in patients with SLE, and no work has been found in the literature on periodontal surgery and its impact on the healing process, given that inflammatory processes are considered triggers for SLE activation, if not controlled. The objective of this work is to demonstrate, through a clinical case, the importance of dental practice in conjunction with medicine in assisting patients with SLE. A periodontal prevention protocol, free gingival graft surgery and orthodontic treatment were performed, which greatly favored the patient's function, aesthetics and quality of life. This is the first study that demonstrates the importance of lupus control according to rheumatological indexes and describes important dental aspects of the healing of patients with this systemic condition. Clinical interventions performed in patients with SLE require a multiprofessional approach,
\end{abstract}

*Corresponding author: Julien Rodrigues Pires, Discipline of Periodontics, Department of Prosthodontics and Periodontics, School of Dentistry at Bauru, University of São Paulo, Bauru, Brazil, Tel: +55 1432358366; +55 61981351053 , E-mail: julienrpires@gmail.com; julienrpires@usp.br

Citation: Pires JR, de Albuquerque SWC, Dos Santos-Neto LL, Pessoa L, Sant'Ana ACP (2020) Gingival Grafts for Orthodontic Treatment: Is it Possible to Perform them in a Conventional Way in Patients with Systemic Lupus Erythematosus? Int J Case Rep Ther Stud 2: 14.

Received: October 23, 2020; Accepted: November 06, 2020; Published: November 12, 2020

Copyright: (c) 2020 Pires JR, et al. This is an open-access article distributed under the terms of the Creative Commons Attribution License, which permits unrestricted use, distribution, and reproduction in any medium, provided the original author and source are credited. as several factors in the immune, repair and drug response must be considered for success, in addition to assessing other associated morbidities.

Keywords: Diagnosis; Inflammation; Periodontitis; Systemic lupus erythematosus

\section{Introduction}

Systemic lupus erythematosus (SLE) is a chronic, multisystemic inflammatory disease, of unknown cause and of an autoimmune nature, characterized by the presence of several autoantibodies [1]. It is a relatively rare disease with a greater predilection for women than for men, in a 10: 1 ratio [2]. SLE can affect any region of the body, considering that the autoantibody (anti-DNA) is able to affect any region that contains DNA, that is, any part of the body [1].

Because there is no cure, the disease is characterized by periods of activity and inactivity. The control of disease activity is performed mainly by the use of corticosteroids and other immunosuppressants. As it is a serious disease, it is extremely important that diagnosis and treatment be carried out as soon as possible. Serological tests can be used to assess the disease, the most important being the determination of anti-DNA antibodies and other criteria that are part of the American Academy of Rheumatology [3].

Among the parameters to check if the disease is active in the patient, the SLEDAI (Systemic Lupus Erythematosus Disease Activity Index) is the index most used in medical practice, as it is the most sensitive to changes in disease activity and is easy to apply. SLEDAI is a parameter measure for the prognosis of patients with SLE. There must be periodic monitoring of these patients to characterize the high risk for some patients who should be monitored more closely. Patients with SLEDAI $\leq 2$ are considered to have no lupus activity [4]. These weights are added together resulting in a final score (maximum 105), the higher the higher the degree of disease activity [1].

The finding of irreversible damage or sequelae resulting from the disease can be measured using the SLICC (Systemic Lupus International Collaborating Clinics). This index can be stable or increase over time and has a maximum of 47 points [1].

Treatments performed with SLE patients require a multiprofessional approach, as several factors in the immune, repair and medication response must be considered, in addition to assessing other associated morbidities. There are few studies in the literature that mention periodontal treatment in patients with SLE [5-7]. Problems such as periodontal disease, gingival recession, malocclusion, among others, demonstrate a problem to these patients.

The objective of this work is to show, through a clinical case, the follow-up and dental assistance to a patient with SLE.

\section{Clinical Case Report}

Female patient, 42 years old, white, with SLE, had chronic periodontal disease and generalized inserted gum loss, attended for dental treatment, as she reported frequent gingival inflammation, especially 
Citation: Pires JR, de Albuquerque SWC, Dos Santos-Neto LL, Pessoa L, Sant'Ana ACP (2020) Gingival Grafts for Orthodontic Treatment: Is it Possible to Perform them in a Conventional Way in Patients with Systemic Lupus Erythematosus? Int J Case Rep Ther Stud 2: 14.

in the lower anterior teeth and uncomfortable with smile esthetics (Figures $1 \&$ 2). In medical history, she reported having SLE for 18 years, having gone through several severe periods of disease activity, with a history of kidney involvement, anemia and several stages of hospitalization.

The patient was using Tecnomed ( 8 tablets weekly), Prednisone $2.5 \mathrm{mg}$, Enalapril 10mg, Folic Acid (1 comp./week), Ferrous sulfate and Miracalcium associated with the use of vitamin D.

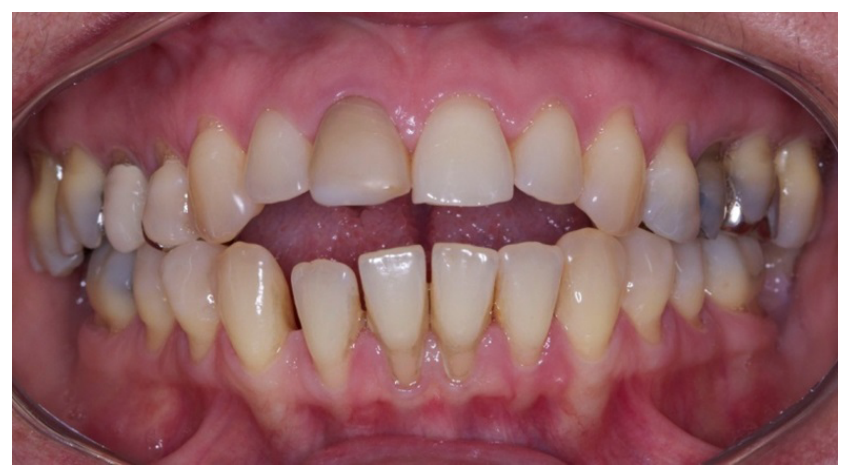

Figure 1: Initial oral clinical aspect of the patient with SLE.

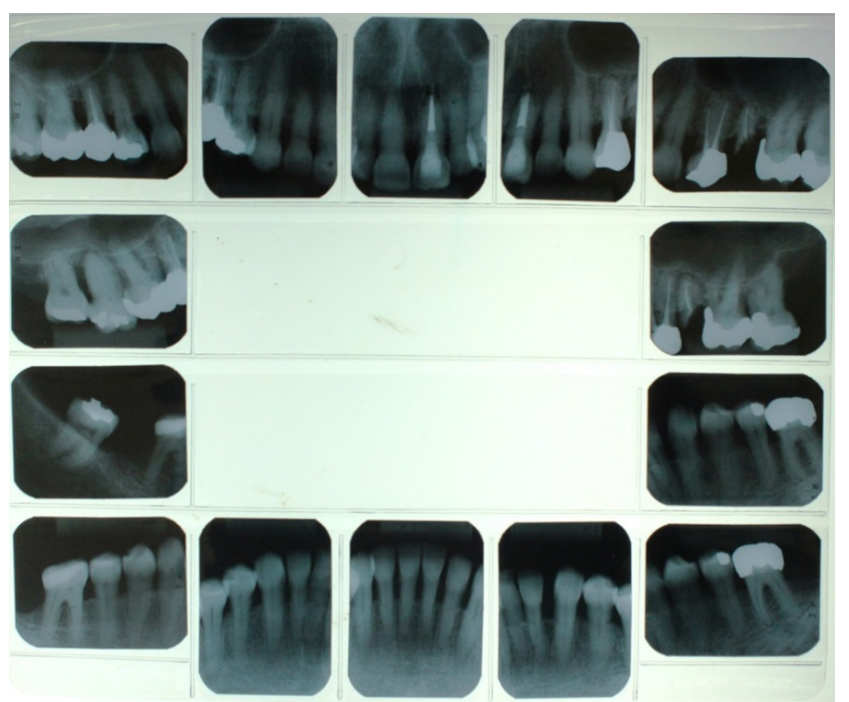

Figure 2: Periapical radiographs requested from the patient before the initial periodontal treatment.

Initially, all data regarding rheumatological treatment were obtained. The patient had a SLEDAI $=2$ and SLICC $=0$. A SLEDAI up to 2 shows that the patient is inactive and the SLICC at zero, shows that the patient had no sequelae of the disease. The value of 2 corresponded to the anti-DNA that was reagent. Occasionally, patients may experience reactive anti-DNA values and other periods as non-reactive. One of the factors that most contributes to this activation of autoantibodies is exposure to sunlight.

The patient reported that she had had greater exposure to the sun during this period, which justifies the fact that anti-DNA gave a reagent.

In view of the patient's stable SLE, scaling and root planing and oral hygiene guidance were initially planned.The initial plaque index was $93 \%$ and gingival bleeding index $17 \%$. The patient was diagnosed with chronic moderate periodontal disease, after periodontal probing of six sites (V, MV, DV, L, ML, DL) per tooth.

Periodontal treatment was performed consisting of scaling and root planing of all teeth with periodic maintenance so that the patient had improvement and awareness about the good control of plaque to start other dental treatments.

At figure 3 we see the region between teeth 42 to 32 had limited gingival insertion and was aggravated by the insertion of the lip brake. Therefore, free gingival graft (EGL) surgery was planned, as proposed by several authors and we can see at figure 4 clinical appearance after scaling and root planing [8-12].

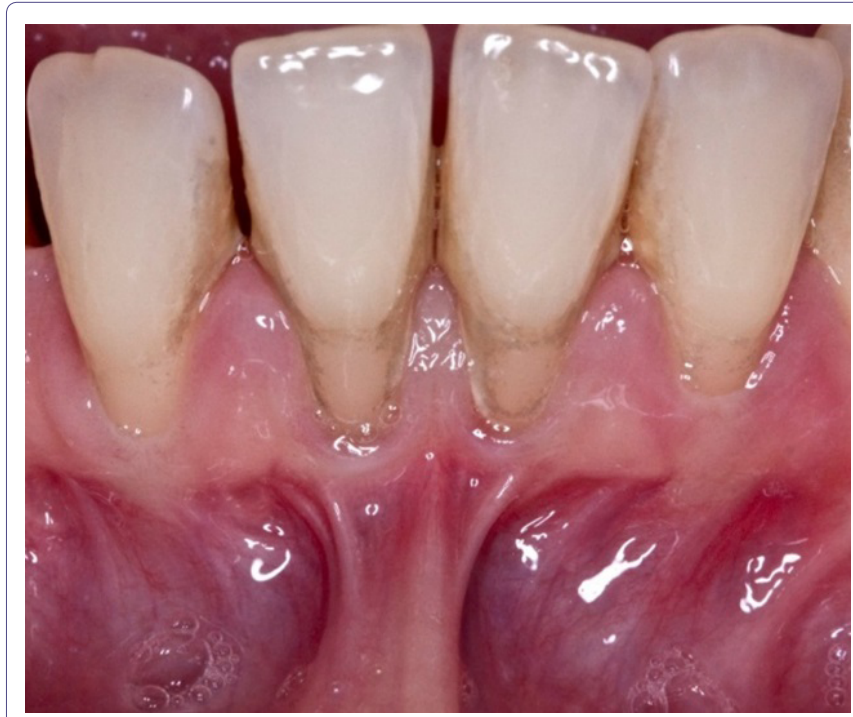

Figure 3: Demonstration of gingival recession, insertion of the lower lip brake in the marginal gingiva and presence of plaque and calculus.

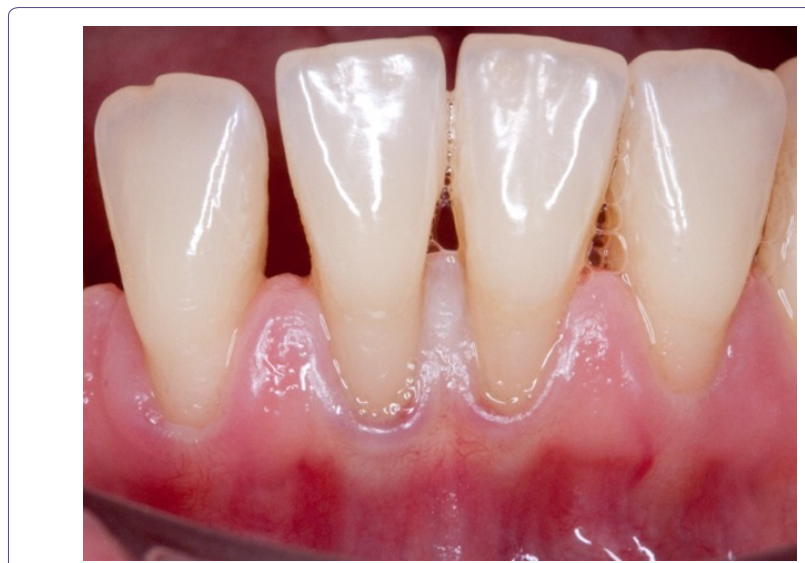

Figure 4: Clinical appearance after scaling and root planing.

Initially, the concern was in relation to the patient's systemic condition, which after consultation with a rheumatologist, proved stable as mentioned earlier. However, there are no reports in the literature on the success or failure of regenerative surgery in patients with SLE. It is known that any inflammatory process can contribute to activate lupus activity, and the performance of a proposed gingival surgery could be a trigger. However, the patient needed periodontal intervention in order to improve the patient's oral appearance. The surgical 
Citation: Pires JR, de Albuquerque SWC, Dos Santos-Neto LL, Pessoa L, Sant'Ana ACP (2020) Gingival Grafts for Orthodontic Treatment: Is it Possible to Perform them in a Conventional Way in Patients with Systemic Lupus Erythematosus? Int J Case Rep Ther Stud 2: 14.

area was delimited, a bed of connective tissue was prepared to receive the graft and the area for the graft was delimited in millimeter $(\mathrm{mm})$ (Figure 5). After preparing the recipient bed, a map for the recipient site was made and the EGL was removed from the hard palate region for donation and suturing with absorbable 4-0 thread (Vycril - Johnson \& Johnson).

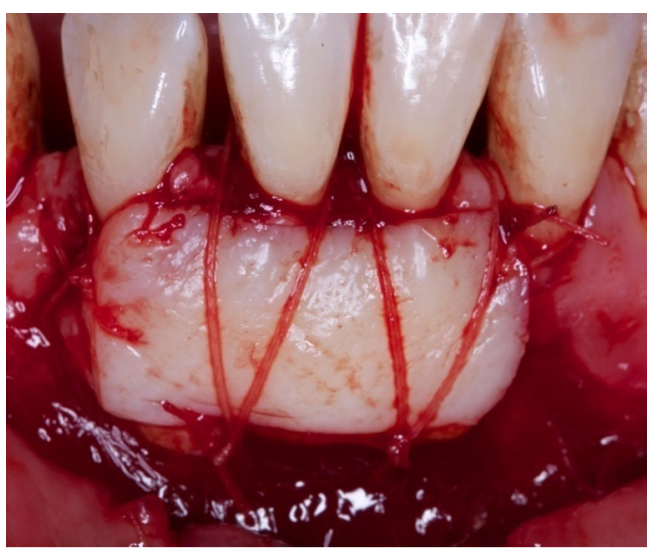

Figure 5: Demonstration of EGL adaptation in the receiving bed.

The donor site and the graft are protected and the postoperative period was monitored for baseline (Figure 6), 7, 14, 21 days and subsequently analyzed at 3 months and finally at 5 years (Figure 7).

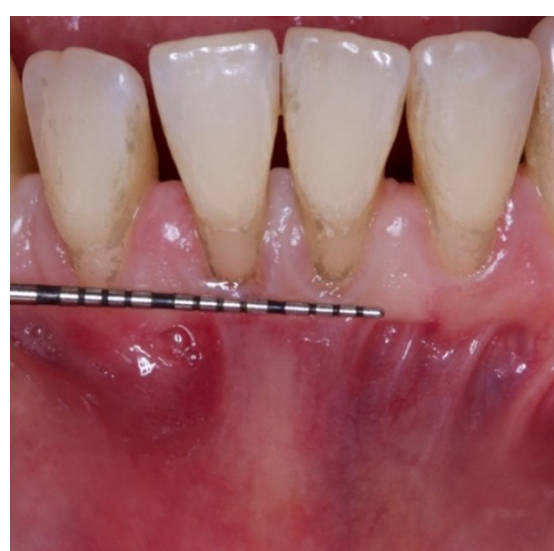

Figure 6: Before EGL surgery.

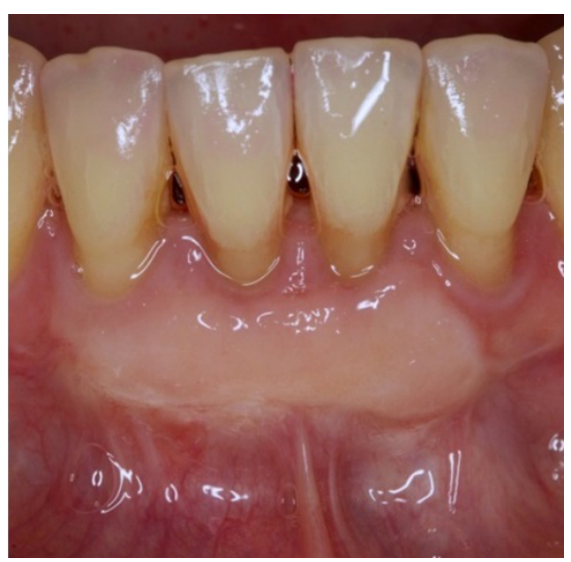

Figure 7: After: 5 years after EGL.
Amoxicillin 500mg, 01 capsule every $8 \mathrm{~h}$ for 7 days was prescribed. Anti-inflammatory was not recommended, as the patient has a history of kidney disease, although controlled and was using corticosteroids.

After six months of EGL surgery and good plaque control, the patient was referred for orthodontic treatment. Because there are also no reports in the literature about orthodontic treatment in SLE patients after years of using corticosteroids and because the patient has periodontal disease with periodontal pocket in several places, a challenging treatment was planned together with the orthodontist, as the patient had anterior open bite in adulthood.

There was a doubt about a higher risk of developing bone loss due to the chronic use of many years of corticosteroids. It was verified in some moments, even with minimal force applied by the orthodontist, tooth mobility that questioned the patient's prognosis. Several months of frame stability, without the application of orthodontic force during maintenance, were necessary.

The patient had already sought treatment in other clinics, but without success, as they were reluctant to treat her due to the severity of the case and the presence of the disease Lupus.

Radiographic examinations, photographs, cephalometric analyzes and study model were requested prior to orthodontic treatment. After clinical evaluation and complementary exams, the patient's malocclusion was diagnosed and orthodontic planning was performed (Figures $8 \& 9)$.

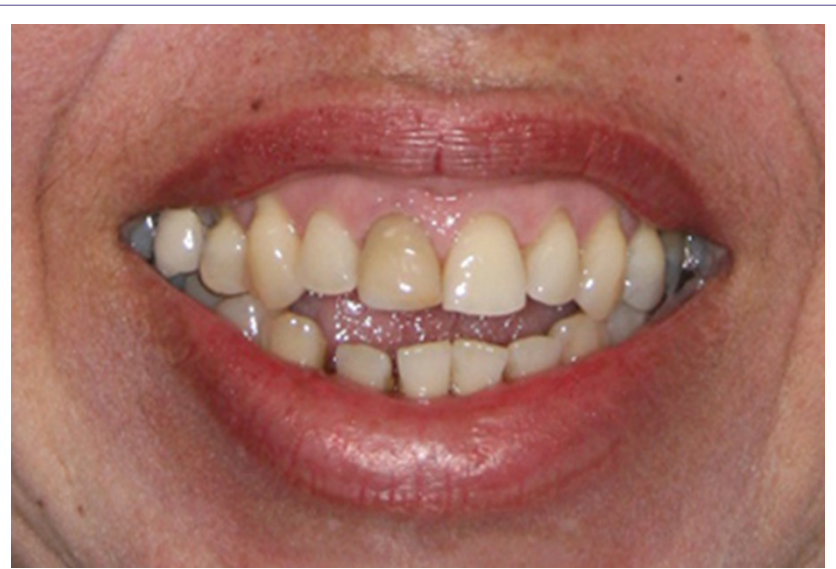

Figure 8: Smile of the initial patient individual occlusion.

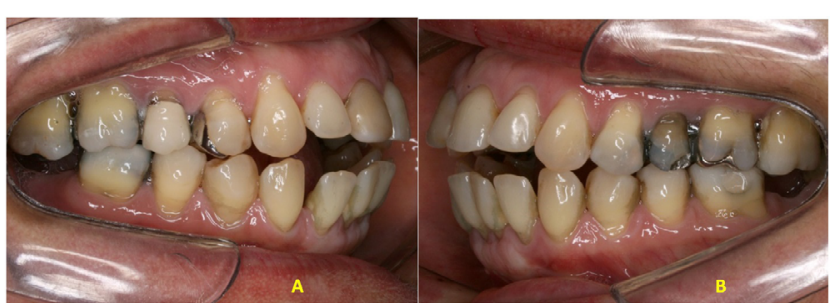

Figure 9: A: Right side view. B. Left side view.

On examination, the patient had: symmetrical face, vertical growth tendency, enlarged lower third of the face, absence of lip sealing and convex profile. Normal lip and lingual brake, normal size tongue and interposition at rest, when swallowing and speaking. The shape of the upper and lower arch was normal, the occlusion had a molar ratio 
Citation: Pires JR, de Albuquerque SWC, Dos Santos-Neto LL, Pessoa L, Sant 'Ana ACP (2020) Gingival Grafts for Orthodontic Treatment: Is it Possible to Perform them in a Conventional Way in Patients with Systemic Lupus Erythematosus? Int J Case Rep Ther Stud 2: 14.

of $3 / 4$ Class II of Angle and a canine ratio of $1 / 2$ class II on the right side and on the left side. She had an anterior open bite of more than 10 $\mathrm{mm}$, vestibularized upper and lower anterior incisors and with lower diastemas.

The fixed orthodontic treatment was proposed with the objective of closing the anterior open bite with intrusion of the posterior teeth, extrusion of the anterior teeth, initiating the bonding of the orthodontic appliance through the lower arch (Figure 10).

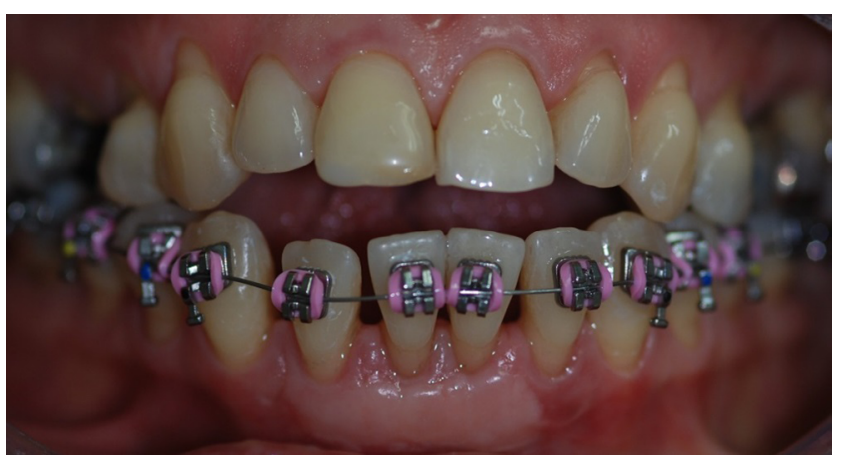

Figure 10: Smile after bonding lower arch.

Due to the difficulty of the patient to attend with the appropriate frequency for dentist appointments, it was necessary to do the extraction of teeth 15 and 25 (Figure 11). This facilitated the closing the spaces of the extractions, helping to close the open bite, displacing the upper incisors.

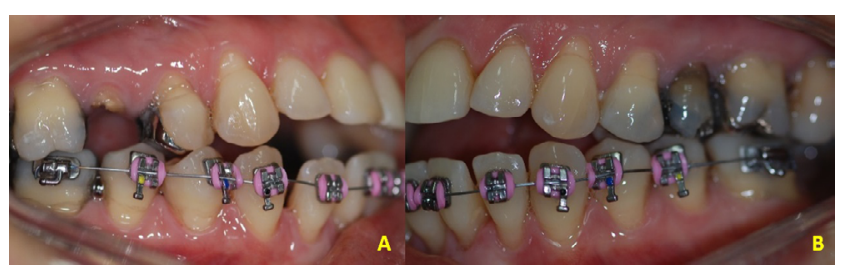

Figure 11: A: Right side view. B. Left side view. After bonding lower arch.

The proposed treatment aimed to grant the patient the best benefit within the limitations of tooth movement. Therefore, the movement was smooth, with light forces aiming at the maximum preservation of the teeth and the bone level, this caused the orthodontic treatment to take 4 years (Figure 12), a longer time than that predicted in the literature for periodontal patients $[13,14]$. Whenever possible, it is necessary to shorten the duration of orthodontic treatment to prevent worsening of periodontitis.

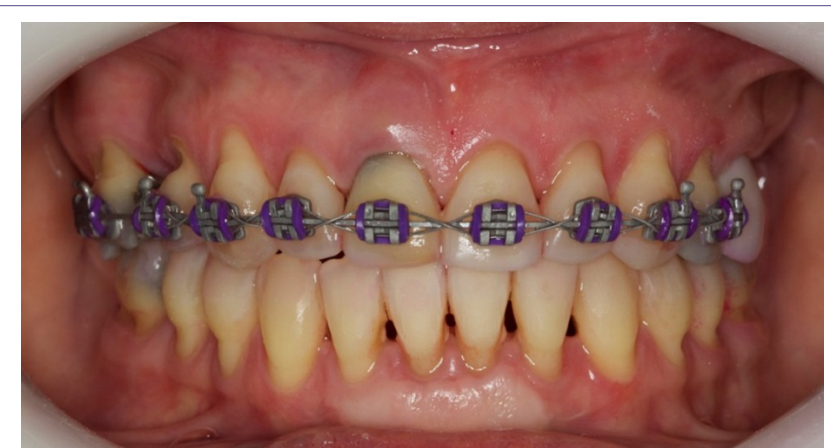

Figure 12: Clinical aspect being completed after 4 years of orthodontic treatment.
During orthodontic treatment, panaroamic radiographs were taken to assess the evolution and control of movement and bone level (Figure 13). Some clinical interventions were made, such as periodic periodontal scrapes; hygiene instructions; endodontics of the tooth 27 , where there was no regression of the periapical lesion - endo-perioid lesion - after endodontic treatment; extraction of teeth 17, 27, 28 and 38 and exchange of restorations of teeth 14 and 24 for indirect restorations (ceromer onlay).

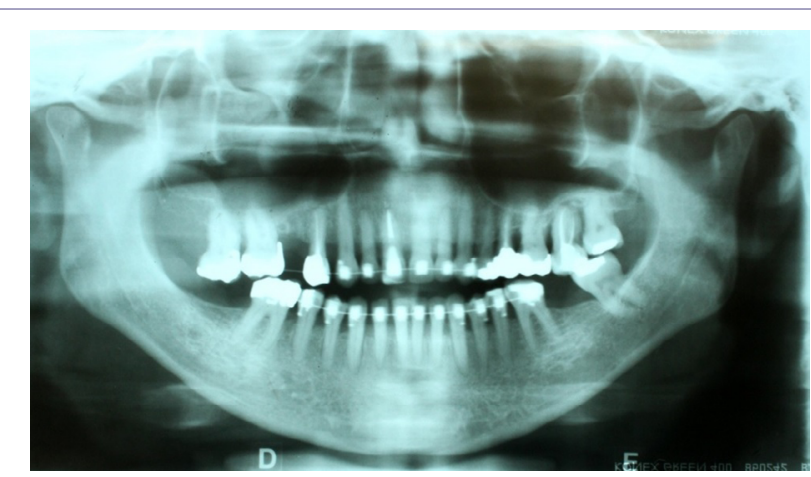

Figure 13: Panoramic radiography to control orthodontic treatment.

After the case was completed, the fixed appliance was removed and Hawley-type mobile retainers were made in both arches. The patient was referred to periodontics for completion of surgical periodontal treatment. After the periodontal treatment, the fixed retention was placed to prevent relapse.

\section{Discussion}

Treatments performed on patients with systemic lupus erythematousus require a multidisciplinary and multiprofessional approach. SLE must be accompanied by a rheumatologist and there is a need for frequent drug treatment in order to keep the disease inactive $[3,15,16]$. In this case report, the patient was using control medications with minimal dosage, as she had her SLE controlled, without major systemic involvement.

The Dental Surgeon requires team monitoring in order to provide a better therapeutic approach and to avoid confusion in the diagnosis, since there are several similar aspects among other types of lupus and even other oral diseases $[7,17,18]$. Antibiotic therapy associated with the surgical procedure was used, due to the risk that the patient has of developing some type of infection, as she is considered an immunosuppressed patient due to the frequent use of corticosteroids.

Proof of predilection for women is highly demonstrated in studies with the disease. Studies reporting men with SLE are rare $[11,16]$.

SLEDAI and SLICC are arguably methods of characterizing disease activity $[1,4]$. It is always necessary to use them for the evaluation of SLE. In case of positive evaluation, inactivity of the disease, it is allowed to do any type of procedure necessary for the patient's health, including oral, even surgery.

Despite the low prevalence of oral lesions and poor periodontal conditions in patients with SLE [7] special care is needed for these patients due to the low immunity they have, which makes them more susceptible to the acquisition of other diseases. Also taking into account the inflammatory process of periodontal disease in association with lupus activity and the fact that SLE patients are immunosuppressed $[6,19]$. 
Citation: Pires JR, de Albuquerque SWC, Dos Santos-Neto LL, Pessoa L, Sant 'Ana ACP (2020) Gingival Grafts for Orthodontic Treatment: Is it Possible to Perform them in a Conventional Way in Patients with Systemic Lupus Erythematosus? Int J Case Rep Ther Stud 2: 14.

The high rate of plaque and the low rate of gingival bleeding is in agreement with several authors in the literature $[4,19]$. This is because the chronic use of corticosteroids prevents the typical reaction of the inflammatory condition. However, the bacteria are still present and continue to degenerate the periodontal apparatus [20].

The method used in this case report to solve the patient's gingival recession is one of the most chosen among the surgeries that solve this problem. It is possible to predict a satisfactory result $[9,10,11]$. Even in patients with SLE, if the disease is controlled, the use of the correct medications can even decrease the amount of periodontal pockets present in patients [21].

The literature does not report orthodontic treatments in patients with systemic lupus erythematosus. In our study, we observed a longer time than that predicted in the literature for periodontal patients in orthodontic treatment $[13,14]$ in a patient with SLE and periodontal disease. Due to the activity and inactivity that SLE patients present, the frequency of consultations ends up being more spaced and increasing the expected time. Whenever possible, it is necessary to shorten the duration of orthodontic treatment to avoid worsening periodontitis.

There are few studies in the literature that mention periodontal treatment in patients with SLE. Therefore, this case report is important to alert the need for knowledge in the care of these patients, even avoiding prejudice against the disease.

\section{Conclusion}

Through this case report, it could be observed that health professionals need to know about SLE to obtain the correct diagnosis and offer the correct treatment to SLE patients.

It is necessary that the patient is in adequate conditions for the procedure, characterized by a period of inactivity of the disease and evaluation of several systemic factors, since the disease activity associated with invasive procedures can accentuate the inflammatory damage of lupus.

The patient must be under drug control and rheumatological follow-up, allowing any dental procedure to be performed on patients, even surgical ones, such as free gingival graft. And more research is needed on this topic for a better diagnosis and treatment of patients with systemic lupus erythematosus.

\section{Conflict of Interest}

The authors declare that the research was conducted in the absence of any commercial or financial relationships that could be construed as a potential conflict of interest.

\section{Declaration}

We, the authors of this work, do not receive financial support for research given by organizations that may have gained or lost with the publication of this work. We, or members of our families, did not receive consulting fees or were paid as appraisers by organizations that may have gained or lost from the publication of this work, we have no shares or investments in organizations that may also have gained or lost from the publication this work. We do not receive presentation fees from organizations that for profit may have gained or lost from the publication of this work, we are not employed by the commercial entity that sponsored the study and we do not have patents or royalties, nor do we work as a specialized witness, or perform activities to an entity with a financial interest in this area.

\section{References}

1. Borba EF, Latorre LC, Tavares Brenol JC, Kayser C, da Silva NA, et al (2008) Consenso de Lupus Eritematoso Sistêmico. Revista Brasileira de Reumatologia 48: 196-207.

2. Carranza FA, et al. (2012) Periodontia Clínica. 12.ed., São Paulo: Elsevier, 2012.

3. Freire EAM, Souto LM, Ciconeli RM (2011) Medidas de avaliação em lúpus eritematoso sistêmico. Revista Brasileira de Reumatologia 51: 70-80.

4. Mirzayan MJ, Schmidt RE, Witte T (2000) Prognostic parameters for flare in systemic lupus erythematosus. Rheumatology, Oxford 39: 1316-1319.

5. Miceli V, et al. (2005) Associação entre a doença periodontal e o lupus eritematoso sistêmico. Revista Ciência Medicas Biológicas 4: 150-157.

6. Meyer U, Kleinheinz J, Gaubitz M, Schulz M, Weingart D, et al. (1997) Oral manifestations in patients with systemic lupus erythematosus. Mund Kiefer Gesichtschirurgie1: 90-94.

7. Umbelino Júnior A, Cantisano MH, Mendes Klumb E, Pedra Dias E, da Silva AA, et al. (2010) Achados bucais e laboratoriais em pacientes com lúpus eritematoso sistêmico.Jornal Brasileiro de Patologia e Medicina Laboratorial 46: 479-486.

8. De Carvalho Farias B, Ferreira B, De Melo RSA, Moreira MF, de Melo Valença AS (2009) VCirurgias periodontais estéticas: revisão de literatura. International Journal of Dentistry 8: 160-166.

9. Feitosa D, Santamaria MP, Sallum EA, Nociti Junior FH, Casati MZ, et al. (2008) Indicações atuais dos enxertos gengivais livres. Revista Gaúcha de Odontologia, Porto Alegre 56: 1-6.

10. Silva CO, Ciotti DL, Sallum AW, Casati MZ (2006) Evaluation of basic periodontal therapy outcome using clinical and microbiological parameters. Periodontia 16: 30-34.

11. Sousa JNL, Dantas LS, Sousa RL (2013) Enxerto gengival livre: recobrimento de recessão associado ao aumento da mucosa ceratinizada. Revista COOPEX 4: 1-8.

12. Bouchard P, Malet J, Borghetti A (2001) Decision-making in aesthetics: root coverage revisited. Periodontology 21: 97-120.

13. Han JY (2015) A comparative study of combined periodontal and orthodontic treatment with fixed appliances and clear aligners in patients with periodontitis. J Periodontal Implant Sci 45: 193-204.

14. Levin L, Einy S, Zigdon H, Aizenbud D, Machtei EE (2012) Guidelines for periodontal care and follow-up during orthodontic treatment in adolescents and young adults. J Appl Oral Sci 20: 399-403.

15. Alves VLP, Carniel AQ, , Costallat LLT, Turato ER, et al. (2014) Significados do adoecer para pacientes com lúpus eritematoso sistêmico: revisão de literatura. Revista Brasileira de Reumatologia 55: 522-527.

16. Albilia JB, Lam DK, Clokie CML, Sándor GKB (2007) Systemic Lupus Erythematosus: A review for dentists. Journal of the Canadian Dental Association 73: $823-828$.

17. Lourenço SV, de Carvalho FRG, Boggio P, Sotto MN, Vilela MAC, et al. (2007) Lupus erythematosus: clinical and histopathological study of oral manifestations and immunohistochemical profile of the inflammatory infiltrate. Journal Cutan Pathol 34: 558-564.

18. Ribeiro DS, Neto CA, D’Almeida F, Galvão VL, Santiago MB (2011) Achados de imagem das alterações musculoesqueléticas associadas ao lúpus eritematoso sistêmico. Radiologia Brasileira 44: 52-58.

19. Pessoa LC (2011) Análise dos níveis de proteína C-reativa ultra-sensível e de doença periodontal em pacientes com lúpus eritematoso sistêmico. 2011. 64 f. Dissertação (Mestrado em Ciências Médicas)-Universidade de Brasília, Brasília, 2011. 
Citation: Pires JR, de Albuquerque SWC, Dos Santos-Neto LL, Pessoa L, Sant'Ana ACP (2020) Gingival Grafts for Orthodontic Treatment: Is it Possible to Perform them in a Conventional Way in Patients with Systemic Lupus Erythematosus? Int J Case Rep Ther Stud 2: 14.

- Page 6 of 6 -

20. Pessoa L, Aleti G, Choudhury S, Nguyen D, Yaskell T, et al. (2019) Host-Microbial Interactions in Systemic Lupus Erythematosus and Periodontitis. Front. Immunol 10: 2602.
21. Mutlu S, Richards A, Maddison P, Scully C (1993) Gingival and periodontal health in systemic lupus erythematosus. Community Dent Oral Epidemiol Copenhagen 21: 158-161. 


\section{H}

Advances In Industrial Biotechnology | ISSN: 2639-5665

Advances In Microbiology Research | ISSN: 2689-694X

Archives Of Surgery And Surgical Education | ISSN: 2689-3126

Archives Of Urology

Archives Of Zoological Studies | ISSN: 2640-7779

Current Trends Medical And Biological Engineering

International Journal Of Case Reports And Therapeutic Studies | ISSN: 2689-310X

Journal Of Addiction \& Addictive Disorders | ISSN: 2578-7276

Journal Of Agronomy \& Agricultural Science | ISSN: 2689-8292

Journal Of AIDS Clinical Research \& STDs | ISSN: 2572-7370

Journal Of Alcoholism Drug Abuse \& Substance Dependence | ISSN: 2572-9594

Journal Of Allergy Disorders \& Therapy | ISSN: 2470-749X

Journal Of Alternative Complementary \& Integrative Medicine | ISSN: 2470-7562

Journal Of Alzheimers \& Neurodegenerative Diseases | ISSN: 2572-9608

Journal Of Anesthesia \& Clinical Care | ISSN: 2378-8879

Journal Of Angiology \& Vascular Surgery | ISSN: 2572-7397

Journal Of Animal Research \& Veterinary Science | ISSN: 2639-375

Journal Of Aquaculture \& Fisheries | ISSN: 2576-5523

Journal Of Atmospheric \& Earth Sciences | ISSN: 2689-8780

Journal Of Biotech Research \& Biochemistry

Journal Of Brain \& Neuroscience Research

Journal Of Cancer Biology \& Treatment | ISSN: 2470-7546

Journal Of Cardiology Study \& Research | ISSN: 2640-768X

Journal Of Cell Biology \& Cell Metabolism | ISSN: 2381-1943

Journal Of Clinical Dermatology \& Therapy | ISSN: 2378-8771

Journal Of Clinical Immunology \& Immunotherapy | ISSN: 2378-8844

Journal Of Clinical Studies \& Medical Case Reports | ISSN: 2378-880

Journal Of Community Medicine \& Public Health Care | ISSN: 2381-1978

Journal Of Cytology \& Tissue Biology | ISSN: 2378-9107

Journal Of Dairy Research \& Technology | ISSN: 2688-9315

Journal Of Dentistry Oral Health \& Cosmesis | ISSN: 2473-6783

Journal Of Diabetes \& Metabolic Disorders | ISSN: 2381-201X

Journal Of Emergency Medicine Trauma \& Surgical Care | ISSN: 2378-8798

Journal Of Environmental Science Current Research | ISSN: 2643-5020

Journal Of Food Science \& Nutrition | ISSN: 2470-1076

Journal Of Forensic Legal \& Investigative Sciences | ISSN: 2473-733X

Journal Of Gastroenterology \& Hepatology Research | ISSN: 2574-2566
Journal Of Genetics \& Genomic Sciences | ISSN: 2574-2485

Journal Of Gerontology \& Geriatric Medicine | ISSN: 2381-8662

Journal Of Hematology Blood Transfusion \& Disorders | ISSN: 2572-2999

Journal Of Hospice \& Palliative Medical Care

Journal Of Human Endocrinology | ISSN: 2572-9640

Journal Of Infectious \& Non Infectious Diseases | ISSN: 2381-8654

Journal Of Internal Medicine \& Primary Healthcare | ISSN: 2574-2493

Journal Of Light \& Laser Current Trends

Journal Of Medicine Study \& Research | ISSN: 2639-5657

Journal Of Modern Chemical Sciences

Journal Of Nanotechnology Nanomedicine \& Nanobiotechnology | ISSN: 2381-2044

Journal Of Neonatology \& Clinical Pediatrics | ISSN: 2378-878X

Journal Of Nephrology \& Renal Therapy | ISSN: 2473-7313

Journal Of Non Invasive Vascular Investigation | ISSN: 2572-7400

Journal Of Nuclear Medicine Radiology \& Radiation Therapy | ISSN: 2572-7419

Journal Of Obesity \& Weight Loss | ISSN: 2473-7372

Journal Of Ophthalmology \& Clinical Research | ISSN: 2378-8887

Journal Of Orthopedic Research \& Physiotherapy | ISSN: 2381-2052

Journal Of Otolaryngology Head \& Neck Surgery | ISSN: 2573-010X

Journal Of Pathology Clinical \& Medical Research

Journal Of Pharmacology Pharmaceutics \& Pharmacovigilance | ISSN: 2639-5649

Journal Of Physical Medicine Rehabilitation \& Disabilities | ISSN: 2381-8670

Journal Of Plant Science Current Research | ISSN: 2639-3743

Journal Of Practical \& Professional Nursing | ISSN: 2639-568

Journal Of Protein Research \& Bioinformatics

Journal Of Psychiatry Depression \& Anxiety | ISSN: 2573-0150

Journal Of Pulmonary Medicine \& Respiratory Research | ISSN: 2573-0177

Journal Of Reproductive Medicine Gynaecology \& Obstetrics | ISSN: 2574-2574

Journal Of Stem Cells Research Development \& Therapy | ISSN: 2381-2060

Journal Of Surgery Current Trends \& Innovations | ISSN: 2578-7284

Journal Of Toxicology Current Research | ISSN: 2639-3735

Journal Of Translational Science And Research

Journal Of Vaccines Research \& Vaccination | ISSN: 2573-0193

Journal Of Virology \& Antivirals

Sports Medicine And Injury Care Journal | ISSN: 2689-8829

Trends In Anatomy \& Physiology | ISSN: 2640-7752

Submit Your Manuscript: https://www.heraldopenaccess.us/submit-manuscript 